Syntax Literate: Jurnal Ilmiah Indonesia p-ISSN: 2541-0849 e-ISSN: 2548-1398

Vol. 6, No. 10, Oktober 2021

\title{
PERANAN PUBLIC RELATIONS DALAM MENSOSIALISASIKAN PROGRAM VAKSIN COVID-19 DI KOTA BEKASI
}

\section{Euis Atika, Maulana Rifai, Ana Fitriana Poerana}

Universitas Singaperbangsa Karawang (UNSIKA) Jawa Barat, Indonesia

Email: euisatika72@gmail.com, maulana.rifai@staff.unsika.ac.id, ana.fitriana@fisip.unsika.ac.id

\begin{abstract}
Abstrak
Vaksinasi Covid-19 merupakan salah satu cara Pemerintah dalam menanggulangi pandemi saat ini, hal ini perlu adanya komunikasi dan edukasi yang baik antara pihak Pemerintah kepada masyarakat mengenai vaksinasi Covid-19, agar tidak adanya kesimpangsiuran berita mengenai program vaksinasi sehingga terjalin kerjasama yang baik antara pihak Pemerintah dan masyarkat untuk mensukseskan program vaksinasi Covid-19. Dalam penelitian ini bertujuan untuk menjelaskan bagaimana peranan humas Pemerintahan Kota Bekasi dalam mensosialisasikan program vaksinasi Covid-19 kepada masyarakat. Dengan menggunakan teori yang peranan dari Cultip, Center \& Broom dan Teori Instrumental Model of Persuation. Peneliti disini menggunakan metode kualitatif deskriptif dimana dalam penelitian ini bertujuan untuk memahami dan mendeskripsikan bagaimana humas Pemkot Bekasi dalam proses sosialisasi melalui hasil wawancara mendalam dengan narasumber yang diambil berdasarkan teknik purposive sampling. Dari hasil yang di dapat dalam penelitian ini humas Pemerintahan Kota Bekasi sudah melakukan peran humas sebagaimana semestinya berdasarka teori peranan dari Cultip \& Broom, dalam hal ini humas harus tetap melakukan komunikasi terus menerus kepada masyarakat bahwa vaksin itu aman dan halal baik melalui media maupun secara persuasif untuk memaksimalkan proses sosialisasi.
\end{abstract}

Kata Kunci: peran humas; public relations; pemerintahan kota

\section{Abstract}

The Covid-19 vaccination is one of the Government's ways in tackling the current pandemic, this requires good communication and education between the Government and the public regarding the Covid-19 vaccination, so that there is no confusion about the news regarding the program so that good cooperation is established between the Government. and the community to make the Covid-19 vaccination program a success. This study aims to explain how the public relations role of the Bekasi City Government in disseminating the Covid-19 vaccination program to the public. By using theory whose role is from Cultip, Center \& Broom and Instrumental Model of Persuation Theory. The researcher here uses descriptive qualitative method which in this study aims to understand and describe how the public relations of the Bekasi City Government in the socialization process through in-depth interviews with resource persons taken based on purposive sampling technique. From the results obtained in this study, the public relations of the Bekasi

$\begin{array}{lll}\text { How to cite: } & \text { Atika. E., Rifai, M., \& Fitriana, A. (2021) Peranan Public Relations dalam Mensosialisasikan Program } \\ & \text { Vaksin Covid-19 Di Kota Bekasi. Syntax Literate: Jurnal Ilmiah Indonesia, 6(10). } \\ & \text { http://dx.doi.org/10.36418/ Syntax-Literate.v6i10.4350 } & \\ \text { E-ISSN: } & 2548-1398 \\ \text { Published by: } & \text { Ridwan Institute }\end{array}$


City Government has carried out the role of public relations as it should based on the role theory of Cultip \& Broom, in this case public relations must continue to communicate continuously to the public that vaccines are safe and halal both through the media and persuasively to maximize the socialization process.

Keywords: the rol public relations; public relations; city government

Received: 2021-09-20; Accepted: 2021-10-05; Published: 2021-10-20

\section{Pendahuluan}

Pada akhir tahun 2019 lalu muncul sebuah virus baru yang berasal dari China, virus ini disebut dengan Virus Covid-19. Dimana Covid-19 merupakan penyakit yang menyerang saluran pernapasan seperti batuk, pilek, yang bisa menyebabkan ketahap yang lebih serius, seperti Middle East Respiratory Syndrome (MERS) dan Acute Resporatory Syndrome (SARS), virus ini dapat menyerang manusia dan hewan (Kemenkes RI, 2020).

Diawal tahun Januari 2021, tindakan yang dilakukan oleh pemerintah untuk menanggulangi penyebaran virus Covid-19 yaitu dengan cara memberikan vaksinasi kepada masyarakat secara gratis, berdasarkan peraturan Menteri Kesehatan RI No 10 Tahun 2021 terkait pelaksanaan vaksinasi guna untuk menanggulangi penyebaran virus Covid-19 (Kemenkes RI, 2021). Vaksinasi merupakan pemberian vaksin yang bertujuan khusus diberikan untuk menimbulkan atau membentuk kekebalan tubuh seseorang secara aktif terhadap suatu penyakit (Sagala et al., 2020).

Dalam program pelaksanaan vaksinasi, Indonesia memiliki target sebanyak 426,8 juta dosis yang harus di vaksinasi untuk mencapai heard immunity atau kekebalan kelompok (Kemenkeu, 2021). Program vaksinasi dilakukan diberbagai wilayah dengan tingkat prioritas penyebaran Covid-19 yang cukup tinggi dan secara bertahap serta dibagi menjadi beberapa gelombang vaksinasi (Muhammad et al., 2021). Salah satunya Kota Bekasi dimana Bekasi adalah kota yang berada di tingkat penyebaran Covid-19 nya tinggi, berdasarkan data yang didapatkan dari website corona Bekasi. Data kasus Covid-19 di Kota Bekasi sendiri pada 27 Juni 2021 tercatat total keseluruhan yang terkonfirmasi adalah 51.651 kasus positif Covid-19 (Corona.bekasi.go.id, 2021).

Dengan adanya program vaksinasi yang dilakukan oleh pihak pemerintah, tak sedikit masyarakat Indonesia masih meragukan vaksin Covid-19, sehingga permasalahan vaksinasi masih menjadi kontroversi di kalangan masyarakat. Hal ini terjadi dikarenakan banyaknya beredar beberapa informasi hoax yang beredar di masyarakat, khususnya di media sosial yang sangat mempengaruhi, mengenai kandungan yang ada didalam vaksin, mengenai halal-haramnya vaksin, efektivitas dan keamanan vaksin, serta masih banyak lagi (Arumsari et al., 2021). 


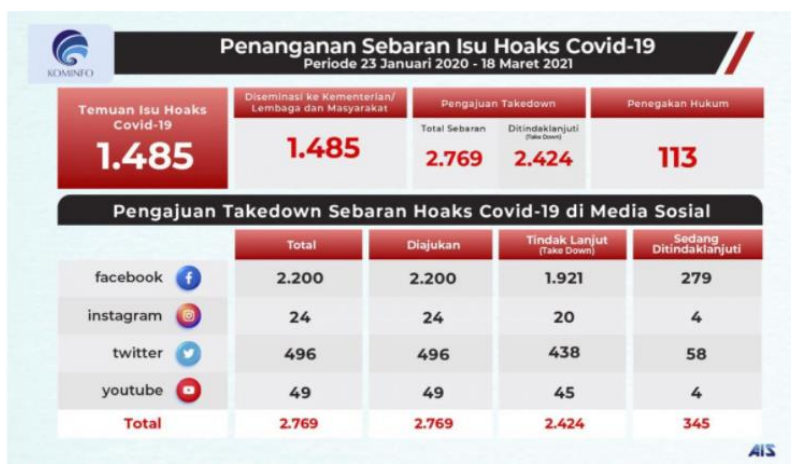

Gambar 1

\section{Data Hoax Vaksinisasi}

Sumber: (https://www.kominfo.go.id/content/detail/33348/penanganan-sebaran-isuhoaks-covid-19-kamis-18032021/0/infografis. 2021)

Berdasarkan gambar diatas peringkat penyebaran hoax di Indonesia cukup tinggi, Dimana hoax tersebut beredar di sosial media seperti facebook, instagram, twitter, youtube berdasarkan dari data yang didapatkan dari kominfo per tanggal 23 Januari sampai 18 maret 2021sebanyak 2.769 total temuan hoaks vaksin yang beredar dimasyarakat melalui media sosial kementrian komunikasi dan informatika menindak lanjuti pemberitaan yang berbau hoax dengan meninjak lanjut atau mentakedown informasi tersebut dengan total kasus yang sudah di tindak lanjut sebanyak 2.424 kasus dan proses sedang dilanjut sebanyak 345 kasus (Kominfo, 2021).

Terkait banyaknya berita kesimpangsiuran mengenai vaksinasi sehingga menimbulkan keraguan masyarakat mengenai persepsi mengenai vaksin Covid-19. Peran pemerintah saat ini, sangat perlu untuk mengambil langkah dan pendekatan yang efektif kepada masyarakat. Hal ini berguna untuk mendapatkan kepercayaan dan perubahan sikap masyarakat yang masih meragukan vaksin Covid-19 sehingga proses vaksinasi ini dapat dilakukan guna untuk mempercepat penanggulangan menangani pandemic serta tercapainya herd immunity yang memerlukan cakupan vaksinasi sebanyak 70\% masyarakat Indonesia (Artuti \& Dewi, 2021). Sehingga dibutuhkan informasi yang tepat dan efektif dari pemerintah mengenai program vaksinasi Covid-19 kepada masyarakat, agar program vaksinasi ini berjalan dengan lancar. Hal ini berguna agar terciptanya transparasi dan informasi yang tepat kepada masyarakat, Dalam menyampaikan informasinya

Sejalan dengan adanya program vaksinasi dan kunjungan Presiden Republik Indonesia pada pelaksanaan vaksinasi massal sesuai surat edaran No.443.1/715/set.Covid-19 yang dilaksanakan pada 19 Juni 2021di Stadion Patriot Chandrabaga di Kota Bekasi (Bekasikotago.id, 2021). Memberikan edukasi serta informasi yang tepat terhadap masyarakat dalam hal program vaksinasi covid-19 yang dilakukan, merupakan hal yang penting untuk health education mengenai program vaksinasi covid-19 (Kholdiyah et al., 2021).

Dalam suatu daerah pemerintah memiliki divisi yang biasanya disebut dengan humas, yang berada dalam struktur Sekretariat Daerah. Peran humas dalam suatu 
Pemerintahan merupakan hal yang penting untuk berkomunikasi baik terhadap internal maupun eksternal (Sa'diah, 2018). Penyampaian mengenai program vaksinasi dapat dilakukan humas, karna informasi mengenai program vaksinasi diberikan dari pihak yang memiliki otoritas yang lebih tinggi kepada masyarakat, bertujuan guna untuk mempengaruhi masyarakat untuk merubah sikap, mengurangi kecurigaan dan ketakutan masyarakat yang timbul karena banyak informasi salah yang beredar dimasyarakat karena adanya kurang informasi dan edukasi yang diketahui masyarakat (Talib et al., 2021).

Humas disini memiliki peran sebagai mediator yang menjembatani dalam mensosialisasikan berbagai kegiatan program yang dilakukan Pemerintahan Kota Bekasi (Wahyuningrum, 2017). Peran Humas Pemerintahan Kota Bekasi disini bertujuan untuk mengedukasi, mensosialisasikan dan mengajak masyarakat agar dapat berkontribusi dengan pihak pemerintah untuk melaksanakan program vaksinisasi guna mencegah penyebaran virus Covid-19 di Kota Bekasi (Nasir et al., 2021).

Fokus dalam penelitian ini terkait bagaimana pemerintah khususnya seorang public relations dalam mensosialisasikan program vaksinasi covid-19 kepada masyarakat, khususnya masyarakat di Kota Bekasi. Hal ini bertujuan agar masyarakat mendapatkan informasi dan edukasi yang jelas terkait program vaksinasi covid-19 agar masyarakat mau dan ikut berpartisipasi dalam program yang dilakukan pemerintah untuk menanggulangi pandemi saat ini. Penelitian sejenis juga telah dilakukan oleh Sri Praptono, Rekno Sulandjari, Heru Sriwulan pada tahun, dimana dalam penelitian tersebut bertujuan mengenai seberapa besar efektifitas peran public relations civitas akademika mengenai sosialisasi vaksin covid-19, dimana dalam penelitian tersebut menggunakan metode penelitian kuantitatif atau menggunakan kuisoner dalam pengambilan datanya dalam menentukan seberapa besar keefektifan peran public relations tersebut (Praptono et al., 2020). Servience Imelda Nubatonis, juga melakukan penelitian dengan menitik beratkan bagaimana peran seorang public relations dalam penelitian tersebut menghasilkan bahwa tidak semua public relations memiliki peran yang sama dalam menjalankan suatu sosialisasi, seorang PR memiliki caranya sendiri dalam mensosialisasikan suatu program yang ada (Nubatonis Servince Imelda, 2015).

Tujuan dari penelitian ini adalah, untuk mengetahui bagaimana peran seorang public relations dalam mensosialisasikan program vaksin covid-19 kepada masyarakat dengan menggunakan landasan teori peranan menurut menurut Dozier dan Broom yaitu peran humas sebagai penasihat ahli, humas sebagai fasilitator komunikasi, humas sebagai pemecah masalah dan humas sebagai teknisi komunikasi (Lalihatu et al., 2017).

Berdasarkan latar belakang yang telah diuraikan, maka peneliti tertarik untuk melakukan penelitian tentang bagaimana Peran Humas Kota Bekasi dalam mensosialisasikan penggunaan vaksin Covid-19, karna peran pemerintahan sangat dibutuhkan dalam kondisi saat ini, untuk mengajak masyarakat ikut berpartisipasi dalam program vaksin covid-19 sehingga program vaksinasi di Kota Bekasi berjalan dengan lancar dan mencapai herd immunity. 


\section{Metode Penelitian}

Menurut (Sugiyono, 2017) Metodelogi penelitian adalah metode ilmiah untuk memperoleh data yang memiliki maksud dan tujuan tertentu. Metode ilmiah di klasifikasikan sebagai aktivitas penelitian berdasarkan karakteristik ilmiah yaitu, rasionalitas, pengalaman, dan sistemik. Adapun dalam penelitian ini penulis menggunakan metode penelitian kualitatif, dimana dalam penelitian ini memiliki ciri khusus yang tidak dapat menggunakan data statistik, tetapi lebih menitik beratkan dengan cara mengamati orang lain, berinteraksi dan berusaha untuk memahami. Sejalan dengan definisi metode penelitian tersebut, Krik dan Miller mendefinisikan bahwa penelitian kualitatif merupakan ilmu pengetahuan sosial yang secara fendumental bergantung dari hasil pengamatan langsung pada manusia, baik dalam lingkungan maupun peristilahannya dengan menggunakan latar ilmiah dengan bertujuan menafsirkan suatu fenomena yang terjadi dengan melibatkan berbagai metode yang ada (Moeleong, 2014).

Dapat disimpulkan bahwa dalam penelitian ini metode yang digunakan adalah metode kualitatif dengan studi deskriptif, dimana penelitian ini bertujuan untuk mengkaji suatu fenomena yang dialami subjek penelitian baik perilaku, tindakan, persepsi, dan lain-lain dari hasil yang telah di dapat dengan mengamati perilaku subjek penulis dapat mendeskripsikan perilaku subjek dan peneliti berperan sebagai instrument kunci (Sugiono, 2013). Sehingga dalam penelitian ini mengembangkan sebuah hubungan yang khusus dengan beberapa pihak, sehingga informasi yang didapatkan dapat dimengerti secara efesien. karena penelitian kualitatif adalah penelitian yang menggunakan latar alamiah, dengan memahami suatu makna dan fenomena yang terjadi melalui hasil wawancara mendalam dengan narasumber, dimana dalam penelitian kualitatif penulis adalah instrument kunci (Sugiyono, 2017).

1. Sumber Data

Sumber data dan informan bisa di dapatkan melalui dua cara yaitu melalui Data Primer dan data Sekunder. Data Primer adalah data yang diperoleh secara langsung dengan menggunakan teknik wawancara terhadap informan, dan melakukan observasi. Dan Data Sekunder adalah data pendukung yang dikumpulkan penulis baik melalui buku yang berkaitan dengan penelitian ini, media online, ebook, dan karya ilmiah yang dapat mendukung kebutuhan informasi yang terkait dengan penelitian ini (Burhan, 2003).

2. Teknik penentuan Informan

Dalam penentuan informan penulis menggunakan teknik purposive sampling, dimana purposive sampling merupakan sebuah penelitian penulis lebih cenderung memilih responden yang dianggap sebagai sumber data yang dapat dipercaya dan diyakini sebagai sumber data yang efektif dan mengetahui permasalahan yang diambil (Sutopo, 2009:56) Kriteria informan dalam penelitian ini yaitu staf humas Pemerintahan Kota Bekasi yang khususnya berkaitan langsung mengenai sosialisasi program vaksinasi Covid-19 di Kota Bekasi.

3. Teknik Analisis Data 
Dalam penelitian ini menggunakan analisis data kualitatif, artinya data tersebut merupakan hasil yang diperoleh dalam penelitian yang dilaporkan apa adanya dan kemudian di analisis secara deskriptif untuk mendapatkan gambaran fakta yang ada dan mampu mendiskripsikan secara detail apa saja yang didapatkan oleh penulis selama pengumpulan data (Idrus, 2009).

4. Lokasi penelitian dilakukan di Sekretariat Daerah Pemerintah Kota Bekasi pada Bagian Humas Pemerintahan Kota Bekasi, dimana peneliti melakukan wawancara secara langsung bersama para informan yang telah dipilih, dengan Kasubbag Hubungan Dokumentasi Internal, Staff Humas Publikasi Eksternal dan Staff Humas Fasilitas Hubungan Media dan Kunjungan Daerah.

\section{Hasil dan Pembahasan}

Mengenai Peran public relations humas Kota Bekasi dalam rangka mensosialisasikan program Vaksinasi Covid-19 di Kota Bekasi yaitu berdasarkan teori peran public relations menurut Dozier dan Broom yang terdiri dari sebagai penasihat ahli, fasilitator komunikasi, pemecah masalah dan teknisi komunikasi dalam mensosialisasikan program vaksinasi Covid-19.

1. Peran Public Relations Humas Pemerintahan Kota Bekasi Sebagai Penasihat Ahli

Berdasarkan hasil wawancara yang telah dilakukan penulis kepada pihak humas Pemerintahan Kota Bekasi, peranan humas Kota Bekasi sebagai penasihat ahli adalah dengan cara memberikan saran berdasarkan permasalahan yang terjadi sebelumnya, khususnya program vaksinasi. Maka dari itu, humas akan melaksanakan tahap perencanaan mengenai rekomendasi atau masukan yang akan disampaikan kepada pihak manajemen, hal ini tidak terlepas dari komunikasi dengan stakeholder yang ada. Dalam sosialisasi dan edukasi yang dijalankan humas diperuntukan untuk publik internal maupun eksternal, tergantung situasinya. Dalam hal ini humas sebagai penasihat ahli dengan cara memberikan sosialisasi kepada masyarakat mengenai program vaksinasi dan mengedukasi masyarakat agar masyarakat ikut serta dalam mensukseskan program vaksinasi di Kota Bekasi.

Berdasarkan penjelasan penelitian diatas, menurut penulis Humas Pemerintahan Kota Bekasi dalam menjalankan perannya sebagai penasihat ahli sudah menjalankan perannya dengan baik. Dimana seorang humas terlibat dalam menangani suatu permasalahan, baik di internal maupun eksternal berdasarkan hasil wawancara yang dilakukan oleh penulis.

2. Peran Public Relations Humas Pemerintahan Kota Bekasi Sebagai Fasilitator Komunikasi

Berdasarkan hasil wawancara yang didapat mengenai humas sebagai fasilitator komunikasi yaitu dengan cara memfasilitasi setiap pertemuan yang dibutuhkan, baik itu secara kunjungan daerah, media ataupun dengan stakeholder lainnya. Hal ini bertujuan untuk memfasilitasi informasi yang dibutuhkan. Sebagai humas fasilitator dalam mensosialisasikan program vaksinasi yang dilakukan oleh Pemerintahan Kota 
Bekasi peran humas disini adalah sebagai mediator dalam menyampaikan suatu informasi mengenai suatu kebijkan atau program yang akan dilakukan Pemerintah.

Dalam mensosialisasikan program vaksinasi di Kota Bekasi, humas melakukan berbagai cara agar masyarakat mendapatkan informasi dan ikut berpartisipasi dalam menjalankan program vaksinasi yang diadakan pemerintah untuk mencegah penyebaran Covid-19. Salah satunya yaitu menggunakan platform humas Kota Bekasi baik melalui website, media sosial seperti instagram, twitter, facebook. media lainnya juga ada media cetak seperti pemasangan baliho, spanduk dan poster, serta menggunakan media elektronik seperti televisi dan radio. Menurut dari hasil wawancara untuk saat ini cara yang paling efektif untuk melakukan sosialisasi yaitu dengan menggunakan media internet karena cakupannya yang luas dan cepat. Dalam hal sosialisasi humas juga melakukan kerjasama dengan berbagai pihak media yang memang cakupannya luas dalam penyampaian informasi, hal ini bertujuan untuk memperluas informasi yang dikeluarkan oleh pihak humas sendiri. Agar sosialisasi menjadi lebih maksimal, serta membentuk tim sosialisasi secara langsung dengan membentuk tim patriot untuk melakuka sosialisasi terjun ke wilayah-wilayah, aksi tersebut dinamakan dengan "Woro-Woro".

3. Peran Public Relations Humas Pemerintahan Kota Bekasi Sebagai Pemecah Masalah Menurut hasil dari wawancara dengan Humas Pemerintahan Kota Bekasi, humas sudah melakukan perannya dengan baik sebagai humas pemecah masalah. Humas sendiri harus sensitif dan peka serta aktif terhadap suatu pemberitaan yang ada di media. Pemerintahan Kota Bekasi cukup cepat tanggap mengenai isu yang ada.

Permasalahan yang muncul dalam program vaksinasi ini adalah berita hoax di media sosial, sehingga hal ini banyak warga yang masih meragukan dan takut untuk melakukan vaksinasi. Peran humas kota bekasi disini berperan dalam menangani permasalahan yang ada dan harus memberikan solusi dalam menanangani suatu permasalahan. Dalam hal ini, Humas Pemerintahan Kota Bekasi akan menelusuri dan menganalisis permasalahan tersebut serta melibatkan OPD terkait dalam mengambil kesimpulan untuk mendapatkan informasi yang valid. Ketika sudah mendapatkan informasi yang valid maka humas akan mengklarifikasi melalui media sosial milik humas Kota Bekasi.

Dari hasil yang didapat saat melakukan sosialisasi secara langsung ke masyarakat, ternyata masih banyak juga masyarakat yang masih takut untuk melakukan vaksinasi peran humas disini melakukan pendekatan secara persuasif dengan melakukan edukasi terhadap masyarakat yang ditemuinya. Peran Humas disini juga terus memberikan informasi dan edukasi mengenai program vaksinasi bahwa vaksin itu aman dan halal baik melalui media maupun secara langsung.

4. Peran Public Relations Humas Pemerintahan Kota Bekasi Sebagai Teknisi Komunikasi

Peran teknisi komunikasi menjadikan PR sebagai journalist in recident yang hanya menyediakan layanan teknis komunikasi atau dikenal dengan methode of 
communication in organization. Peran PR dalam penyebaran informasi secara massal sangat penting, teknik penyampaiannya yang baik kepada masyarakat sangat penting untuk menjembatani hak partisipasi yang sedang dibangun. Humas juga berperan dalam menampung, mengolah aspirasi masyarakat, membentuk opini publik yang baik, mengklarifikasi informasi suatu berita yang berkembang dimasyarakat serta mensosialisasikan dan mempublikasikan program instansi terhadap masyarakat.

Komunikasi yang dilakukan oleh PR tidak harus bersifat langsung, komunikasi tidak harus dilakukan dengan cara bertatap muka, komunikasi dapat dilakukan melalui media lain, seperti realese, bulletin ataupun brosur dan lain sebagainya baik melalui online ataupun tidak, dalam hal ini harus menghasilkan timbal balik berupa informasi yang dibutuhkan.

Humas Pemerintahan Kota Bekasi dalam mensosialisasikan program vaksinasi Covid-19 menggunakan media dalam penyampaiannya baik melalui media digital, media elektronik maupun media cetak. Media digittalnya dengan menggunakan website untuk menyebarkan release dan media sosial dalam sosialisasinya seperti menggunakan instagram, twitter dan facebook, hal ini lebih efektif dalam memberikan sosialisasi kepada masyarakat karna media sosial yang cakupannya sangat luas. Media cetak menggunakan baliho, brosur, spanduk yang ditempatkan di tempat-tempat strategis yang mudah dijangkau dari perhatian masyarakat.Sedangkan media elektronik menggunakan radio dan televisi untuk sosialisasinya.

Dalam pembahasan ini, penulis akan menguraikan hasil penelitian terhadap Humas Pemerintahan Kota Bekasi dalam mensosialisasikan program Covid-19 di Kota Bekasi dengan mengacu pada teori utama yang digunakan dalam penelitian ini yaitu teori instrumental model of persuation.

Dalam penelitian ini penulis menggunakan teori instrumental model of persuation dari Hovland, Jenis and Kelly. Teori ini adalah proses komunikasi persuasif, dimana seorang individu atau komunikator mengirim rangsangan secara verbal. Hal ini bertujuan untuk mengubah perilaku, perubahan sikap seseorang ataupun perubahan persepsi yang ada di masyarakat melalui jenis komunikasi yaitu stimuli, intervening dan response.

1. Stimuli

Stimuli adalah suatu rangsangan eksternal terhadap komunikan berupa karakteristik dari situasi komunikasi yang dititik beratkan kepada kredibilitas komunikator yang meliputi suatu keahlian (expertise), keterpercayaan (trusttworthines), dan kesukaan (likebility). Dalam peran humas Pemerintahan Kota Bekasi dalam mensosialisasikan program vaksin Covid-19 di Kota Bekasi yaitu dengan cara menggunakan media untuk menyampaikan informasi mengenai program vaksinasi, baik berupa media cetak (koran, baliho, spanduk dan poster), media online (website Kota Bekasi, instagram, facebook, twitter), dan media elektronik (televise dan radio). Humas juga melakukan kerjasama dengan pihak media lain dengan tujuan untuk menyampaikan informasi lebih luas kepada masyarakat, khususnya masyarakat Kota Bekasi. Tidak hanya menggunakan 
media saja humas Kota Bekasi juga melakukan woro-woro dalam proses sosialisasinya, dimana humas melakukan sosialisasi secara langsung dan secara persuasif kepada masyarakat setiap harinya.

\section{Intervening}

Intervening merupakan perhatian, pemahaman, dan penerimaan turut mempengaruhi proses komunikasi dan bagaimana efek komunikasi, dalam hal intervening meliputi perhatian, pemahaman dan penerimaan komunikan (masyarakat) terhadap pesan yang sudah diberikan oleh pihak humas Kota Bekasi. Dalam hal ini variabel yang tidak dapat diukur dan diamati secara langsung karena proses yang terjadi didalam benak maupun pikiran kita, tetapi variabel ini dimanfaatkan untuk mempredeksi suatu respon.

Dalam hasil penelitian, hal ini dapat dilihat dari platform yang disediakan oleh humas Kota Bekasi, salah satunya akun media sosial instagram humas Kota Bekasi dimana proses komunikasi tersebut dapat diterima di masyarakat. Hal ini dapat dilihat dari respon masyarakat di akun media sosial tersebut melalui kolom komentar, dimana banyak masyarakat yang menanggapi dan antusias dalam merespon informasi yang diberikan oleh humas Kota Bekasi. Tidak hanya melalui media, hal ini dapat dilihat saat humas melakukan sosialisasi secara langsung banyak masyarakat yang merespon dengan baik penyampaian informasi yang diberikan oleh humas Kota Bekasi, tetapi dalam proses sosialisasi ini masih ada beberapa masyarakat yang masih kurang memahami pentingnya vaksinasi untuk melawan pandemi saat ini.

\section{Response}

Dari hasil sosialisasi yang telah diberikan oleh humas Pemerintahan Kota Bekasi, mengenai program vaksinasi yang dijalankan Pemerintah diharapkan untuk dapat mendapatkan perubahan mengenai persepsi masyarakat terhadap vaksin Covid-19, dan tentunya perubahan sikap dan perilaku masyarakat.

Dari hasil wawancara yang di dapat respon masyarakat mengenai program vaksinasi ini sangat baik dan masyarakat sangat antusias dengan adanya program vaksinasi yang ada, dan ikut serta melakukan program vaksinasi yang dilakukan. Hal ini dapat dilihat bahwa progress pencapaian vaksinasi Covid-19 di Kota Bekasi berada di urutan 10 di daerah Jawa Barat berdasarkan keterangan dari narasumber dan postingan di website bekasikota.go.id.

\section{Kesimpulan}

Setelah melakukan analisis kualitatif yang telah dilakukan pada Humas Pemerintahan Kota Bekasi dengan judul Peranan Humas Kota Bekasi dalam Mensosialisasikan Program Vaksinasi Covid-19, maka dapat disimpulkan peranan humas Pemerintahan Kota Bekasi sebagai penasihat ahli telah menjalankan perannya sebagai penasihat ahli dengan cara memberikan memberikan masukan dalam menangani suatu permasalahan, berdasarkan setiap pelaksanaan suatu program sehingga 
memiliki landasan yang kuat, serta berperan aktif dalam melakukan sosialisasi mengenai program vaksin sebagai seseorang yang berpengalaman dan professional.

Peranan hunas Pemerintahan Kota Bekasi sebagai fasilitator komunikasi dengan menjadi penghubung antara pihak perusahaan dengan para pemangku kepentingannya atau stakeholder, dalam sosialisasinya humas melakukan sosialisasi dan edukasi kepada masyarakat melalu media, baik media sosial, media cetak, media elektronik dan sosialisasi secara persuasif atau langsung. Humas kota bekasi juga melakukan komunikasi dua arah melalui URC 150044 dan whatsapp humas Kota Bekasi.

Peran humas Kota Bekasi sebagai pemecah masalah dengan cara menganalisis suatus permasalahan dan menelusuri permasalahan tersebut dan berkordinasi dengan OPD lain untuk mendapatkan informasi dan menyimpulkan suatu permasalahan. Dan dalam proses pelaksanaan program vaksinasi humas selalu memberikan informasi dan mengedukasi masyarakat bahwa vaksin itu aman dan halal.

Peranan humas Kota Bekasi sebagai Teknisi Komunikasi dengan membuat sebuah realese dan menyebarkan lewat website Pemerintah Kota Bekasi dan wartawan, serta memberikan informasi mengenai kegiatan yang dilakukan Pemerintah melalui media sosial seperti instagram, twitter dan facebook, melalui media cetak seperti pamflet, brosur dan media elektronik seperti televise dan elektronik. Humas kota Bekasi juga menjalin kerjasama dengan pihak media bertujuan untuk menyebarluaskan informasi lebih luas. 


\section{BIBLIOGRAFI}

Artuti, S., \& Dewi, E. (2021). Komunikasi Publik Terkait Vaksinasi Covid 19.Google Scholar

Arumsari, W., Desty, R. T., Eko, W., \& Kusumo, G. (2021). Gambaran Penerimaan Vaksin COVID-19 di Kota Semarang. Indonesian Journal of Health Community 2, 2(1), 35-45-undefined. http://e-journal.ivet.ac.id/index.php/ijheco. Google Scholar

Bekasikotago.id. (2021). Pemkot Bekasi Keluarkan Surat Edaran Pelaksanaan Vaksinasi Massal Covid-19. Google Scholar

Burhan, B. (2003). Analisis Penelitian. Raja Grafindo Persada. Google Scholar

Corona.bekasi.go.id. (2021). Data Sebaran Kota Bekasi. https://corona.bekasikota.go.id/.

Idrus, M. (2009). Metode Penelitian Ilmu Sosial, Pendekatan Kualitatif dan Kuantitatif. Erlangga. Google Scholar

Kemenkes RI. (2020). Apakah Virus Covid-19 itu? https://www.kemkes.go.id/folder/view/full-content/structure-faq.html. Google Scholar

Kemenkes RI. (2021). Permenkes 84-2020 Pelaksanaan Vaksinasi dalam rangka Penanggulangan Pandemi Corona Virus Disease 2019 (Covid-19). Google Scholar

Kemenkeu. (2021). Program Vaksinasi Covid 19 Tantangan Dalam Mewujudkan Herd Immunity. https://anggaran.kemenkeu.go.id/in/post/program-vaksinasi-covid-19tantangan-dalam-mewujudkan-herd-immunity. Google Scholar

Kholdiyah, D., Sutomo, \& Kushayati, N. (2021). Hubungan Persepsi Masyarakat Tentang Vaksin Covid-19 Dngan Kecemasan Saat Akan Menjalani Vaksinasi Covid-19. Keperawatan, 14(2), 8-20. Google Scholar

Kominfo. (2021). Penanganan Sebaran Isu Hoaks Covid-19 Kamis (18/03/2021). https://www.kominfo.go.id/content/detail/33348/penanganan-sebaran-isu-hoakscovid-19-kamis-18032021/0/infografis.

Lalihatu, I. R., Warouw, D. M. D., \& Tulung, L. E. (2017). Peranan Humas Dalam Mensosialisasikan Bpjs Ketenagakerjaan Pada Pedagang Pasar Segar Paal2. EJournal Acta Diurna, VI(3), 1-13. Google Scholar

Moeleong, L. J. (2014). Metodologi Penelitian Kualitatif. PT Remaja Rosdakarya Bandung. Google Scholar

Muhammad, F. F., Yulitania, I., Putri, M. P. O., \& Shihab, M. (2021). Pembentukan Persepsi Mahasiswa Program Studi Ilmu Komunikasi President University tentang 
Vaksinasi Covid-19. Dynamic Media, Communications, and Culture 2021, 2020, 1-11. Google Scholar

Nasir, N. M., Joyosemito, I. S., Boerman, B., \& Ismaniah. (2021). Kebijakan Vaksinasi Covid-19: Pendekatan Pemodelan Matematika Dinamis Pada Efektivitas Dan Dampak Vaksin Di Indonesia. Jurnal ABDIMAS, 4(2), 191-204. Google Scholar

Nubatonis Servince Imelda. (2015). Peran Public Relation Dalam Program Larasita Badan Pertanahan Kabupaten Timor Tengah Utara Di Kelurahan Kefa Tengah. INTERAKSI: Jurnal Ilmu Komunikasi, 4(1), 62-72-72. https://doi.org/10.14710/interaksi.4.1.62-72. Google Scholar

Praptono, S., Sulandjari, R., \& Wulan, Heru, S. (2020). Kolerasi peran public relations civitas akademika dalam sosialisasi pencegahan covid 19 pada masyarakat sekitar universitas pandanaran. Journal of Chemical Information and Modeling, 53(9), 1689-1699. Google Scholar

Sa'diah, A. K. (2018). Manajemen Relasi Hubungan Masyarakat PT. Petrokimia Gresik. In Jurnal Emba (Issue 2). Google Scholar

Sagala, S. H., Maifita, Y., \& Armaita. (2020). Peran Kinerja Unit Hubungan Masyarakat Terhadap Pelaksanaan Vaksinasi Covid 19 Bagi Masyarakat Di Rumah Sakit Kota Bandung. Jurnal Menara Medika, 2(2), 119-127. Google Scholar

Sugiono. (2013). Metodologi Penelitian Kualitatif. Bandung: Alfabeta. Google Scholar

Sugiyono. (2017). Metode Penelitian Kualitatif. Bandung: Alfabeta. Google Scholar

Sutopo, H. (2009). Metode penelitian kualitatif. UNS Press. Google Scholar

Talib, S. R., Kawengian, D. D. V, \& Pasoreh, Y. (2021). Kajian peran humas dalam meningkatkan kepercayaan masyarakat terhadap vaksin sinovac. Universitas Sam Ratulangi Manado, 9(1), 1-6. Google Scholar

Wahyuningrum, K. (2017). Peran Humas Pt. Pln (Persero) Area Samarinda Dalam Program Hemat Listrik Di Kota Samarinda. Google Scholar

\section{Copyright holder:}

Euis Atika, Maulana Rifai, Ana Fitriana Poerana (2021)

First publication right:

Syntax Literate: Jurnal Ilmiah Indonesia

This article is licensed under:

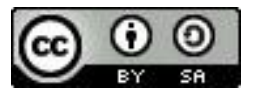

